\title{
EGZYSTENCJA RADYKALNIE ZAKWESTIONOWANA
}

\section{THE RADICAL QUESTIONING OF EXISTENCE}

\section{SUMMARY}

The essay is a continuation of the philosophy of suffering, which the author included in his two books: Understanding Human Suffering and Finding Meaning in Suffering. Its theme is one of the experiences - being abused by someone close that radically questions the existence of the victim and awakens in them the urge to commit suicide. The guiding idea of the text is to draw attention to those abused, have a deeper understanding of them and to stimulate reflection on what can be done, so that such dramatic events could be avoided. The author analyzes the issue of abuse and its effects on the victim's personality, the truth about human nature which abuse reveals, and asks about the possibility of overcoming this harm. The essay borders on phenomenology and existential psychology and expresses the conviction that even someone so hurt is not a lost cause.

KEYWORDS: the philosophy of suffering, the phenomenological method, abuse, self-esteem, suicide, the meaning of life, hope 
W każdym z nas jest kawałek Hioba ${ }^{1}$. Tadeusz Żychiewicz

zarówno fenomenologom, jak i psychiatrom zabroniony jest jeden nastrój, a mianowicie optymizm, który ktoś kiedyś określił jako karykaturę nadziei, która nie zaznała łez ${ }^{2}$.

Paul Ricoeur

prawdziwa afirmacja nadziei, rdzenia ludzkiej egzystencji, może się dokonać jedynie poprzez obietnicę wieczności i zmartwychwstania³.

Paul-Luis Landsberg

\section{Kontynuacja filozofii cierpienia}

Każdy z nas jest w jakimś stopniu, chociaż nie wszyscy się do tego przyznają, człowiekiem cierpiącym. Homo patiens należy do istoty ludzkiej kondycji. Żyjemy w lęku przed możliwym cierpieniem. Boli nas rozstanie, osamotnienie i pustka egzystencjalna. Niekiedy doświadczamy melancholii; na przykład cierpiał na nią wybitny myśliciel Romano Guardini. Chorujemy i starzejemy się. W ludzkim losie pojawiają się również inne bardzo trudne sytuacje i doświadczenia: niepełnosprawność, zaburzenia i choroby psychiczne, alkoholizm i narkomania, życie ze „złym”, trudnym człowiekiem, bezdomność i anonimowość, wykluczenie, bezrobocie i migracja oraz groźne ideologie, fundamentalizm, dyskryminacja, fanatyzm i prześladowania. A życie wszystkich kończy śmierć.

Zadaniem filozoficznego myślenia jest również (przede wszystkim?) rozświetlanie egzystencji, odsłanianie sensu wydarzeń i pomaganie człowiekowi mądrzej żyć. Filozofia powinna zatem również pochylić się z uwagą nad cierpieniem. Peter McCormick mówi: „nie istnieją problemy filozoficzne. Jest za to jedna jedyna rzecz domagająca się poważnego namysłu: wszechobecność cierpienia”" Podobnie pisze Emil Cioran: „Minął czas zajmowania się inteligentnie sprawami powierzchownymi, nieporównanie ważniejszy od sylogizmu

\footnotetext{
${ }^{1}$ T. Żychiewicz, Rok Marka, Kraków 1974, s. 58.

${ }^{2}$ P. Ricoeur, Filozofia osoby, tłum. M. Frankiewicz, Kraków 1992, s. 63.

${ }^{3}$ P.-L. Landsberg, O sprawach ostatecznych, tłum. B. Kazimierczyk, Warszawa 1967, s. 56.

${ }^{4}$ Z filozofii nie ma pożytku. Z Peterem McCormickiem rozmawiaja Czesław Porębski i Michał Bardel, „Znak” 2 (2010), s. 78.
} 
jest problem cierpienia"' I zacytujmy jeszcze znane słowa Józefa Tischnera: „O jakości filozofii decyduje jakość bólu ludzkiego, który chce filozofia wyrażać i któremu chce zaradzać. Kto tego nie widzi, jest blisko zdrady"6.

Czy filozofia wywiązuje się właściwie z tego zadania? Niestety, zasadniczo na ten temat milczy. Paul Ricoeur pisze: „Aczkolwiek bowiem posiadamy pewne dobrze ukonstytuowane tradycje tyczące zła moralnego - grzechu, nie mamy żadnych takich, które dotyczyłyby zła doznanego - cierpienia"”. Oczywiście są wyjątki, zagadnieniem tym zajmowali się w XIX wieku między innymi Schopenhauer i Kierkegaard, a w wieku XX - między innymi Scheler, Jaspers, Weil, Cioran, Frankl, Ricoeur i Tischner.

To prawda: uprawianie filozofii cierpienia napotyka na wiele trudności i przeszkód ${ }^{8}$. Być może decydującą racją tego milczenia jest świadomość bezradności poznania, myślenia wobec skandalu cierpienia, zwłaszcza wobec cierpienia nieusprawiedliwionego i bezsensownego, oraz postawa pokory. Cierpienie jest faktem egzystencjalnym i przeżyciem emocjonalnym. Czy wobec tego można się z nim uporać na drodze czysto intelektualnej? A na dodatek każde cierpienie ma charakter na wskroś indywidualny i niepowtarzalny. Tymczasem opis wszelkiego cierpienia abstrahuje od tego, co w tym zjawisku jedyne i niepowtarzalne. To naturalne, że od tego, co trudne, dotkliwe, staramy się uciekać. Zrozumiałe jest zatem, że również i filozofowie uciekają od cierpienia. Milczenie może być jedną z form tej ucieczki. A w ogóle czy refleksja nad tym bolesnym doświadczeniem może komuś pomóc w zmaganiu się z nim? Czy filozof siedzący przy biurku i popijający kawę jest w stanie zrozumieć człowieka, którego sytuacja jest radykalnie inna? Filozofa powstrzymuje również lęk przed wymądrzaniem się i moralizowaniem.

Jeśli cierpienie nie jest typowym problemem, lecz problemem egzystencjalnym, w istocie zanurzonym $\mathrm{w}$ tajemnicy, to mądrym, adekwatnym ustosunkowaniem się do niego nie jest intelektualne rozważanie go, lecz coś zgoła innego. Refleksja nad cierpieniem wydaje się zarezerwowana dla księży i teologów, dlatego jej podjęcie przez filozofów naraża ich na posądzenie o związki z chrześcijaństwem, a to w sytuacji, gdy Zachód jest nastawiony antychrześcijańsko, jest rzeczą bardzo ryzykowną. A poza tym czy filozof podejmujący

${ }^{5}$ Cyt. za: J. Filek, Filozofia jako etyka, Kraków 2001, s. 145.

${ }^{6} \mathrm{~J}$. Tischner, Myślenie według wartości, Kraków 1982, s. 13.

${ }^{7}$ P. Ricoeur, Skandal zła, tłum. E. Mukoid, „Znak” 12 (1990), s. 48.

${ }^{8}$ Por. J. Galarowicz, Odnaleźć sens w cierpieniu, Kraków 2015, s. 20-24. 
w naszym kraju problem cierpienia nie zostanie uznany za osobę, która pogłębia polskie katolickie „cierpiętnictwo"?

Istnieje jednak wiele racji, które uzasadniają konieczność zajęcia się przez filozofów tym osobliwym problemem9. Po pierwsze - człowiek dąży do zrozumienia spraw najważniejszych, a przecież jedną z nich jest bez wątpienia cierpienie. Po drugie - ponieważ żyjemy w cywilizacji i kulturze, która redukuje prawdę o człowieku do tego, co jest w nim tylko pozytywne, istnieje potrzeba pełnej prawdy antropologicznej - uwzględniającej także to, co jest w nim również negatywne, na przykład cierpienia. Po trzecie - autentyczna filozofia powinna pochylać się z uwagą i troską nad człowiekiem oraz towarzyszyć mu w jego życiu, przeżyciach, losie i dramacie. Sposobem obecności filozofa przy człowieku cierpiącym, formą asystowania jego cierpieniu, jest rozświetlanie mrocznej krainy tej arcytrudnej sytuacji. Po czwarte - kolejnym zadaniem filozofii jest odsłanianie sensu wydarzeń, sytuacji, przeżyć itp., w tym także sensu cierpienia. A jeśli nawet przekracza to możliwości filozoficznego myślenia, filozof powinien wskazać „miejsca”, na przykład religię, gdzie ten sens można znaleźć. Po piąte - filozofia cierpienia powinna również pełnić funkcję pedagogiczną i terapeutyczną, umacniając człowieka cierpiącego w jego człowieczeństwie, rozbudzając lub umacniając w nim nadzieję oraz pomagając mu ustosunkować się do cierpienia adekwatnie. I wreszcie po szóste - misją filozofa jest branie udziału w - mówiąc za Norwidem - „uniepotrzebnianiu nieszczęścia”: zapobieganiu niepotrzebnym, na przykład wynikającym z niewiedzy, cierpieniom, ich usuwaniu itp.

Próbą mojej filozoficznej refleksji nad cierpieniem są dwie książki: Zrozumieć człowieka cierpiacego ${ }^{10}$ oraz Odnaleźć sens $w$ cierpieniu $^{11}$. W pracy Zrozumieć człowieka cierpiącego zajmuję się niektórymi spośród najważniejszych form cierpienia: cierpieniem związanym z rozstaniem, osamotnieniem, pustką egzystencjalną, melancholią, zranioną egzystencją dziecka alkoholika, starzeniem się, chorobą i lękiem. Natomiast główną ideę pracy Odnaleźć sens w cierpieniu można wyrazić w ten sposób: wychodząc od opisu sytuacji człowieka cierpiącego, omawiam próby wyjaśnienia tego przeżycia - przynajmniej niektórych jego form - a przede wszystkim staram się odsłonić jego sens, aby

\footnotetext{
${ }^{9}$ Por. tamże, s. 24-29.

${ }^{10}$ Por. J. Galarowicz, Zrozumieć człowieka cierpiącego, Kraków 2014.

${ }^{11}$ Por. tenże, Odnaleźć sens $w$ cierpieniu, dz. cyt.
} 
przedstawić sposób radzenia sobie z nim, oraz sytuuję ją w perspektywie ostatecznej, o której mówi chrześcijaństwo.

Esej, który Czytelnik ma przed sobą, jest kontynuacją tamtych prac. Rozważam w nim ekstremalną sytuację, szczególnie dramatyczne wydarzenie, arcybolesne przeżycie i skrajną postać zranienia, która kwestionuje $w$ radykalny sposób człowieka oraz rację i sens jego życia.

Mimo że każde takie dramatyczne doświadczenie jest jedyne i niepowtarzalne, istnieje jednak coś, co je wszystkie łączy i zarazem odróżnia od przeżycia radości, nadziei itp. Fenomenologowie to coś nazywają istotą. „Zadaniem myśliciela - pisze Tischner - jest przede wszystkim to - poznać istotę zjawiska"12. Podstawową warstwą mojego eseju jest zatem fenomenologia, opis tego osobliwego zjawiska. Przy tym fenomenologiczny opis może mieć dwojaki charakter: naukowy, „pod mikroskopem”, a więc analityczny, precyzyjny itd., lub luźniejszy, eseistyczny - pozbawiony zasadniczo filozoficznego żargonu, niewchodzący w drobiazgi itp. Wybieram formę eseju. Jest to tekst z pogranicza fenomenologii ejdetycznej, którą uprawiali między innymi Dietrich von Hildebrand i Roman Ingarden, oraz psychologii egzystencjalnej (między innymi Viktor E. Frankl i Rollo May).

\section{Fenomenologia zmaltretowania i sponiewierania}

Sytuacje trudne zdarzają się każdemu z nas. Każdemu znany jest ból i cierpienie. Jednak niekiedy sytuacje i wydarzenia są tak dramatyczne, tak bardzo bolesne, a zranienia tak głębokie, że człowiek traci rację swojego dalszego istnienia. Może to być zdeformowanie ciała, przeżycie osamotnienia, pustki egzystencjalnej i depresji, porzucenie, utrata bliskiej osoby i rozwód, bycie świadkiem rodzinnych awantur, przemocy, okrucieństwa i zabójstwa, bycie obiektem prześladowania i poniżania, które jest nie do wytrzymania; mogą to być trudności życiowe, z którymi nie można sobie poradzić, czy przekonanie, jakie żywił na przykład ojciec Sørena Kierkegaarda, że jest się potępionym przez Boga itd.

Szczególnym wydarzeniem, sytuacją i przeżyciem, osobliwą ekstremalną formą zranienia jest brutalna przemoc, zmaltretowanie i sponiewieranie człowieka przez bliskiego człowieka. Esej poświęcam temu właśnie fenomenowi. Stawiam sobie następujące pytania: co jest istotą tego dramatycznego wydarze-

\footnotetext{
${ }^{12}$ J. Tischner, Wędrówki w krainę filozofów, Kraków 2008, s. 18.
} 
nia? Jakie są jego skutki w osobowości pokrzywdzonego człowieka? Jaka prawda antropologiczna odsłania się w tej sytuacji? Czy po tym arcybolesnym wydarzeniu (ciągu wydarzeń) jest możliwy powrót do - mówiąc językiem Tischnera - „istnienia usprawiedliwionego”? Co należy zrobić, aby tak się stało?

Oto dwa przykłady brutalnego sponiewierania dzieci przez ojca.

Dwudziestopięcioletnia dziewczyna, absolwentka dwóch fakultetów, pracująca w państwowym przedsiębiorstwie, która wielokrotnie stała przed pokusą samobójstwa i wiele razy się kaleczyła, pisze o swojej sytuacji bycia gwałconą przez własnego ojca:

Próbuję odszukać w pamięci obraz mojej matki. Pierwsza rzecz, jaką widzę oczyma serca, to matka płacząca, pełna lęku i strachu, niepotrafiąca mnie ochronić przed furiatyczną obecnością ojca. Matka wychodzi, zostawiając mnie z nim samą. Matka zamykała drzwi, aby tego nie słyszeć. Z czasem przestałam krzyczeć, a ona przestała słyszeć. Tylko pojedyncze spojrzenia od czasu do czasu zdradzały to, iż obie wiemy o zamkniętych drzwiach i rozlegającym się w ciemności krzyku, niesłyszalnym dla uszu. (...) Nauczyłam się z czasem nic nie czuć, nic nie przeżywać. Żeby przetrwać, kaleczyłam ciało, mając nadzieję, iż w ten sposób przestaną, choć na chwilę - boleć rany serca. Jednak po latach na tych ranach zrobiły się ropiejące wrzody, które nie pozwalają nikomu na ich przebicie ${ }^{13}$.

W drugim wydarzeniu, które opisało jedno z pism, uczestniczył ośmiolatek, który nie wywiązał się z narzuconego mu przez ojca obowiązku. Wówczas ojciec się wściekł i, wymierzając mu karę, brutalnie go pobił. Opisując to, chłopiec wyznał, że był kopany jak pies i kilka razy upadł na ziemię. I przyznał się, że po tym fakcie chciał popełnić samobójstwo.

Dwie różne osoby. Dwa odmienne doświadczenia. Podobne sytuacje przeżyły tysiące osób, zwłaszcza kobiet zmaltretowanych przez mężczyzn. Sponiewierane - stawały przed pokusą samobójstwa, ponieważ ich egzystencja została radykalnie zakwestionowana. Co stanowi istotę tej sytuacji, tego wydarzenia i tego przeżycia? Co w takiej sytuacji dzieje się w duszy człowieka?

Sponiewieranie człowieka może mieć dwojaki charakter. Używając terminologii Tischnera ${ }^{14}$, jego źródłem może być - po pierwsze - scena. Osoba może zostać sponiewierana przez życie, przez los - przez chorobę, nieszczę-

${ }^{13}$ K. Wawrzyniczak, Zapiski niekochanego człowieka, „Zeszyty Karmelitańskie” 1 (2007), s. 50.

${ }^{14}$ Por. J. Tischner, Filozofia dramatu. Wprowadzenie, Kraków 1998. 
ście itp. Jednak w sensie ścisłym człowiek jest sponiewierany przez drugiego człowieka. To dramatyczne wydarzenie dokonuje się w przestrzeni międzyosobowej. Nieszczęście, które przychodzi do jednostki od strony sceny - świata, przyrody, na przykład choroba czy powódź - jest również formą zła i zadaje człowiekowi ból. Jeśli natomiast człowiek zostaje zmaltretowany i sponiewierany przez drugiego człowieka, rodzi się zło w sensie ścisłym, a cierpienie z tym związane jest nieporównywalne z nieszczęściem. „Miejscem właściwym zła - pisze Tischner w Filozofii dramatu - jest relacja dialogiczna człowiek drugi człowiek, a nie relacja intencjonalna człowiek-scena świata"15.

Ból związany $\mathrm{z}$ byciem zmaltretowanym i sponiewieranym ulega spotęgowaniu przez fakt, że przychodzi ze strony człowieka, którego miejsce w przestrzeni intersubiektywnej jest szczególne, wyróżnione - ze strony osoby bliskiej, najbliżej: ojca, matki, męża, żony, dziecka itp.

O co chodzi sprawcom tego haniebnego zachowania? Czy kierują się oni intencją zadania człowiekowi bólu, poniżenia go, skatowania, zniszczenia itd.? Oczywiście, również i tak może być. Jednak tak być nie musi, czego dowodzą opisane przeze mnie wydarzenia. Przecież ojciec-gwałciciel córki pragnął czegoś dobrego: miał ochotę sprawić sobie przyjemność. Ojciec zmaltretowanego chłopca również chciał dobrze, ponieważ chciał mu wymierzyć należną karę. Obydwaj rodzice mieli na uwadze jakieś dobro. Chcieli dobrze, a wyrzq$d z i l i$ swoim dzieciom potworne zło. W wydarzeniach tych odsłania się doniosła prawda, że nie wystarczy tylko chcieć dobrze, lecz trzeba wiedzieć, czym jest dobro, potrafić je właściwie rozpoznać i umieć je realizować. A to znaczy między innymi: zauważać, że oprócz mojego dobra, na przykład przyjemności seksualnej, istnieje dobro drugiej osoby, jakim nie jest z całą pewnością jej gwałcenie.

Dla ofiar sponiewierania intencje sprawców tego zła nie mają absolutnie żadnego znaczenia. Dla nich ważne jest jedno: że zostali zaatakowani przez zło, którego autorami są inne osoby, w szczególności ich bliscy.

Do istoty sponiewierania czy zmaltretowania nie należy tylko sam fakt bycia zaatakowanym przez zło, ale charakter tego ataku. W jaki sposób przeżywają ten fakt ofiary tego strasznego zachowania? Otóż doświadczają one grozy sytuacji i brutalności sprawcy. Czują się sponiewierani, zmasakrowani, zmiażdżeni przez zło.

${ }^{15}$ Tamże, s. $187-188$. 
A co tak naprawdę zostało w tym dramatycznym wydarzeniu zaatakowane przez zło? Zło zaatakowało całego człowieka, całe jego jestestwo i wtargnęło $w$ serce jego egzystencji.

Co staje się z okrutnie sponiewieranym człowiekiem? Poszukując odpowiedzi na to pytanie, próbuję przywołać adekwatną metaforę. Czy jest nią metafora zniszczonego drzewa? Jednak w tej sytuacji nie chodzi przecież tylko o złamanie gałęzi; chodzi o coś znacznie więcej. Zmaltretowanie wydaje się raczej czymś podobnym do oblania drzewa obrzydliwą, żrącą, niszczącą, śmierdzącą cieczą. Niekiedy w tej sytuacji drzewo obumiera. A jeśli przeżyje to wydarzenie, ulega skarłowaceniu, zdeformowaniu. Jest to jednak nadal to samo drzewo, ale przecież nie jest już nigdy takie samo. A może wydarzenie sponiewierania oddaje trafniej metafora drzewa złamanego u pnia i przewróconego - spotykam je na spacerze rowerowym nad rzeką Rudawą - które nie jest jednak całkiem oderwane od pnia i nadal żyje, czego dowodem jest to, że co rok na wiosnę pojawiają się na nim zielone liście.

Wprawdzie obydwie metafory oddają trafnie fakt radykalnego zakwestionowania egzystencji s poniewieranego człowieka, jednak nic nie mówią o jego sferze świadomościowo-przeżyciowej. A przecież człowiek zmaltretowany przeżywa z całą mocą to, że całe jego jestestwo zostało zaatakowane i zakwestionowane. Tischner pisze: „Nie wiemy dokładnie, czym jest zło, ani czym jest dobro - wiemy jedno: zło sprawia, że człowiek staje się istnieniem nieusprawiedliwionym, a dobro sprawia, że istnieje istnieniem usprawiedliwionym"16. Tak: człowiek sponiewierany przez drugą osobę czuje, że nie ma żadnej racji, aby dalej istnieć. Radykalnemu zakwestionowaniu, a w skrajnej sytuacji: zniszczeniu, uległo bowiem jego poczucie własnej wartości i godności, przekonanie, że jego życie ma sens, oraz prazaufanie do rzeczywistości i do ludzi. Nastąpiło jakieś pierwotne i fundamentalne zerwanie więzi z życiem.

Pierwszą reakcją na dramatyczne wydarzenie sponiewierania jest zaskoczenie i szok, potworny ból i cierpienie, płacz i rozpacz, lament i skarga. Ricoeur pisze: „kiedy człowiek czuje się ofiarą niegodziwości drugiego człowieka, okrzyk lamentu brzmi najostrzej”'17. Z duszy człowieka wydobywa się krzyk: dlaczego ja? Dlaczego to mnie spotkało? Ricoeur pisze: „Zredukowany do cierpiącego «ja» jestem żywą raną"18.

\footnotetext{
16 Tamże, s. 193.

${ }^{17}$ P. Ricoeur, Zło, tłum. E. Burska, Warszawa 1992, s. 15.

${ }^{18}$ Tamże, Filozofia osoby, dz. cyt., s. 56.
} 
Ofiara zmaltretowania czuje i myśli: ponieważ moja egzystencja została radykalnie zakwestionowana, wyparowało z niej wszelkie dobro, „jestem mniej niż zero", moje życie jest absurdem, „jestem żywą raną" i nie mam żadnej racji, aby nadal istnieć, pragnę tylko jednego: wyrwać się całkowicie z tej sytuacji lub ją przekreślić i unicestwić. Duszę zmaltretowanego człowieka ogarnia tylko jedno pragnienie - pragnienie samobójstwa.

Czy odnosi się to do każdego człowieka sponiewieranego przez drugiego, czy tylko do osób słabych? Czy bandzior zmaltretowany przez drugiego bandziora również żywi takie pragnienie? Chyba jednak przede wszystkim pragnie się zemścić na krzywdzicielu. Moja analiza dotyczy tylko sytuacji takiego sponiewierania, w którym rodzi się pragnienie samobójstwa.

Samobójstwo jest fenomenem uniwersalnym: „Z samobójstwem spotykamy się wszędzie i w każdej epoce historii ludzkości”'19. Czy jest prawdą często głoszone przekonanie, że kochamy życie ponad wszystko? Paul-Luis Landsberg przeczy temu: „To nieprawda, że kochamy życie zawsze i bez względu na wszystko" 20 . Opisane przeze mnie wydarzenia potwierdzają pogląd Landsberga: obydwoje bohaterowie pragnęli bowiem radykalnego przekreślenia swojego istnienia, unicestwienia siebie. Nie jest również sprawiedliwe przypisywanie samobójcy epitetu tchórza ${ }^{21}$.

Landsberg pisze: „W wielu wypadkach ten, kto popełnia samobójstwo, bynajmniej nie czyni tego w intencji unicestwienia własnej osoby, raczej pragnie ją uratować. Bardzo rzadko, a może nigdy, nie dąży do niebytu”22. Czy myśliciel ten ma rację? Czy bohaterowie powyższych dramatycznych opowieści nie chcieli się rzeczywiście unicestwić? Czy tak naprawdę chcieli tylko uratować własną osobę? Nie zgadzam się z Landsbergiem: uważam, że dwudziestopięciolatka i ośmiolatek naprawdę pragnęli uciec w sposób totalny, absolutny od swojego zmaltretowanego, sponiewieranego, złego i nieusprawiedliwionego istnienia.

Niektóre osoby zmiażdżone przez zło faktycznie realizują swoje pragnienie unicestwienia. Inne, które oparły się pokusie samobójstwa, idą przez życie z osobowościowymi skutkami sponiewierania. Czym się charakteryzuje egzystencja radykalnie zakwestionowana, a jednak ocalona?

\footnotetext{
${ }^{19}$ P.-L. Landsberg, O sprawach ostatecznych, dz. cyt., s. 79.

${ }^{20}$ Tamże, s. 80.

${ }^{21}$ Por. tamże, s. 81 i n.

${ }^{22}$ Tamże, s. 92.
} 


\section{Skutki dramatycznego i traumatycznego doświadczenia}

Egzystencja osoby zmaltretowanej i sponiewieranej ma wiele wspólnego $\mathrm{z}$ egzystencją zranioną ${ }^{23}$. Jest to zrozumiałe, ponieważ sponiewieranie jest szczególną, ekstremalną formą zranienia.

Osoba zmaltretowana idzie przez życie $z$ poczuciem $k r z y w d y$ i niesprawiedliwości. Kiedy sobie uświadamia swoją ranę, pyta: dlaczego to właśnie mnie spotkał taki los? Dlaczego zostałem skrzywdzony w taki brutalny sposób? Czy to sprawiedliwe, że ja muszę wędrować przez życie z tym garbem, $\mathrm{z}$ tą raną i bólem, a inni są od tego wolni?

Człowiek, który przeżył tę traumatyczną sytuację, ma kłopoty w relacjach interpersonalnych. Traktując spotkane osoby jako potencjalnych krzywdzicieli, lęka się ich. A jeśli go ktoś faktycznie skrzywdzi, przeżywa to ostrzej i głębiej niż osoby niezranione. I w ogóle ma do ludzi dystans. Często ich unika.

Osoba ta jest zarazem bardzo wyczulona na wszelką krzywdę i niesprawiedliwość, jakiej doświadczają inni ludzie i wspólnoty. Niekiedy to wyczulenie przybiera formę przewrażliwienia.

Skutkiem tego dramatycznego wydarzenia i bolesnego przeżycia jest powracająca i odżywająca wątpliwość co do własnej wartości. Osoby w ten sposób doświadczone mają zaniżone poczucie własnej wartości. Są głodne uznania. Zazdroszczą go innym. Ciągle dążą do umacniania tego poczucia. Dlatego niekiedy odnoszą sukcesy, co i tak nie neutralizuje ich niezadowolenia z siebie. Jeśli są obdarzone zdolnościami i talentami, nie wykorzystują ich w pełni, a niekiedy wręcz je marnują. Często mogłyby uczynić o wiele więcej dobrego niż robią faktycznie, nie pozwala im jednak na to coś w rodzaju psychicznej blokady wynikającej z tego wielkiego zranienia. Zarazem mają one wyostrzony zmysł poczucia własnej godności i godności innych osób. Dlatego tak boleśnie przeżywają obrażanie innych, ich poniżanie, szyderstwo, drwienie itp.

Człowiek jako istota żywa ma pierwotne pozytywne nastawienie do życia i świata, charakteryzuje go samoafirmacja, praufność i nadzieja. Można powiedzieć, że jego elementarną filozofią jest metafizyka dobra i filozofia nadziei. Natomiast akt sponiewierania filozofię tą radykalnie kwestionuje. Odsłania się w nim bowiem twarz absurdu i bezsensu. I narusza korzenie jego pierwotnej solidarności z życiem. Dlatego u zranionego wraca co jakiś czas poczucie bezsensowności i absurdalności życia. Czyha na niego rozpacz. Dzieje się to

\footnotetext{
${ }^{23}$ Por. J. Galarowicz, Zrozumieć człowieka cierpiącego, dz. cyt., s. 99-137.
} 
zwłaszcza w trudnych sytuacjach. Nie zgadzam się z Landsbergiem, który pisze: „człowiek nigdy nie traci nadziei, (...) rozpacz jest aktem niemożliwym, przeciwnym naturze człowieka" ${ }^{24}$.

Elementem konstytutywnym człowieczeństwa są stany emocjonalne i uczucia. Bez tych przeżyć bylibyśmy lodowaci, a w istocie - martwi, bylibyśmy niczym. Ostatecznie to stany emocjonalne i uczucia decydują o urodzie i nędzy ludzkiego życia. (...) Człowiekowi, który nie został zraniony, towarzyszy afirmacja życia, siebie, innych osób i świata oraz - jeśli jest wierzący - Boga. A ta afirmacja wyraża się przede wszystkim w radości życia ${ }^{25}$.

Natomiast u człowieka zmaltretowanego i sponiewieranego ta afirmacja została radykalnie zakwestionowana, korzenie jego egzystencji - mocno naruszone, a pierwotne zaufanie do życia - podważone. Jego życiu towarzyszy zatem nastrój smutku i przygnębienia, a od czasu do czasu pojawiają się stany depresyjne i chandry oraz apatia. Ma on kłopoty z rozrywką i zabawą. Drażni go bowiem fakt, że inni ludzie są radośni i się bawią, a on sam nie potrafi żyć w ten sposób.

Wydawałoby się, że osoby skrzywdzone jednego na pewno nie będą robić: pamiętając, jak same zostały skrzywdzone, nie będą ranić innych. Niestety, istnieje mechanizm psychologiczny polegający na tym, że zraniony - rani, skrzywdzony - krzywdzi, bity - bije itd. Jak to jest możliwe? Prawdopodobnie decydują o tym trzy zjawiska. Jak wiadomo, w zachowaniu bardzo ważną rolę odgrywa naśladowanie. Dlatego kochający - kocha, a krzywdzony - krzywdzi. W eseju Zraniona egzystencja napisałem o osobach skrzywdzonych, które również krzywdzą innych: „Często po prostu i zwyczajnie rozładowują wewnętrzne napięcie i agresję na innych osobach, zwłaszcza najbliższych. Robiąc to, w jakiś sposób minimalizują własny ból. Oczywiście robią to za cenę zadawania bólu innym. Raniąc innych, czują, że w ten sposób dzielą swój ból na dwie osoby" ${ }^{26}$. Pierwotną reakcją na zmaltretowanie i sponiewieranie jest - to zrozumiałe pragnienie odwetu i zemsty. Jeśli nawet zostało ono jakoś „rozbrojone”, przezwyciężone na poziomie świadomości, jest nadal obecne w duszy ofiary w jakiejś, często podświadomej, postaci. I czasem ujawnia się z całą mocą.

Skutkiem brutalnego sponiewierania człowieka może być również, jeśli wcześniej był on osobą wierzącą, ateizm. Skoro dla ofiary tego aktu świat jest

${ }^{24}$ P.-L. Landsberg, W sprawach ostatecznych, dz. cyt., s. 96.

${ }^{25}$ J. Galarowicz, Zrozumieć człowieka cierpiacego, dz. cyt., s. 108-109.

${ }^{26}$ Tamże, s. 131. 
zły, a ludzie są krzywdzicielami lub potencjalnymi krzywdzicielami, trudno im uwierzyć, że istnieje dobry Bóg. Jak bowiem dobry Bóg może dopuszczać do takiego straszliwego zła?

Dopowiedzmy, że niekiedy na skutki analizowanego przeze mnie wydarzenia nakładają się czy się do nich dołączają następstwa innych negatywnych zjawisk, których doświadczają osoby zmaltretowane: alkoholizmu, apodyktycznego czy instrumentalnego ich traktowania itp. Wówczas trud ich istnienia jest spotęgowany.

\section{Odsłona prawdy o człowieku}

Człowiek cierpiący, również zmaltretowany i sponiewierany, ma poczucie absurdalności i skandaliczności tego, co go spotkało. Jednak jako istota, której istnienie jest skierowane ku sensowi, poszukuje także sensu cierpienia. Czy jednak jest możliwy sens brutalnego sponiewierania? Jeśli rzeczywiście niektóre formy cierpienia mają sens, to z punktu widzenia rozumu i doświadczenia zmaltretowanie jest skandalem, czymś całkowicie absurdalnym. Jaki sens miałby być zawarty $\mathrm{w}$ sponiewieraniu, skopaniu własnego syna czy gwałceniu własnej córki? Jacek Filek pisze: „prawdziwym wyzwaniem jest (...) niezawinioność cierpienia, jego bezcelowość, dysfunkcjonalność, a więc jego niesprawiedliwość i bezsensowność”27.

Powyższa teza nie jest równoznaczna $\mathrm{z}$ twierdzeniem, że opisywana sytuacja nie może stanowić podstawy do odkrycia jakiejś istotnej prawdy o rzeczywistości w ogóle, a o człowieku w szczególności. Można przecież zapytać: jakie są warunki możliwości zaistnienia analizowanego fenomenu? Czy byłby on możliwy, gdyby rzeczywistość nie miała ściśle określonego charakteru i gdyby człowiek nie był zbudowany w taki, a nie inny sposób? Czyniąc punktem wyjścia doświadczenie, metoda transcendentalna, którą się posługiwali tacy myśliciele, jak Kant, Husserl, Heidegger, Rahner, Coreth i Lonergan, bada warunki jego możliwości ${ }^{28}$. Znana jest słynna formuła Ricoeura: „Symbol daje do myślenia". Parafrazując ją, można powiedzieć: opisywane wydarzenia dają do myślenia.

To arcybolesne doświadczenie zakłada najpierw określoną metafizykę. Nie wchodząc w szczegóły, odnotujmy tylko dwie uwagi. Rzeczywistość nie jawi się w nim jako zbiór czystych faktów, wydarzeń, procesów itp., lecz jako

\footnotetext{
${ }^{27}$ J. Filek, Filozofia jako etyka, dz. cyt., s. 149.

${ }^{28}$ Por. B.J.F. Lonergan, Metoda w teologii, tłum. A. Bronk, Warszawa 1976.
} 
sfera przeniknięta wartościami i zanurzona w jakimś dobru. Rzeczywistość ma $\mathrm{w}$ istocie charakter agatologiczny. Ta metafizyka agatologiczna została już wyrażona na pierwszych stronach Biblii (to, co Bóg stworzył, było dobre), w Platońskiej idei Dobra i w twierdzeniu św. Tomasza z Akwinu: „byt i dobro są zamienne" (ens et bonum convententur). Jej obrońcami są również współcześni polscy filozofowie: Józef Tischner i Michał Heller. Tischner pisze: „żaden byt jako byt nie nosi w sobie usprawiedliwienia tego, że jest, i tego, czym jest. (...) Istnienie samo przez się nie wyklucza absurdu. Tym, co jest zdolne usprawiedliwić istnienie przedmiotu, jest zawsze jakaś wartośćn" ${ }^{29}$. A oto słowa Hellera: „Dobro jest źródłem Istnienia a Istnienie sprawia, że Dobro jest. (...) Samo Dobro jest - jeżeli tak można powiedzieć - najlepszą z możliwości i dlatego istnieje, i jest źródłem wszystkiego, co jest" ${ }^{30}$.

Gdyby jednak rzeczywistość była samym dobrem, nie doszłoby do tego brutalnego zła. Widocznie jest ona tak skonstruowana, że może się w niej pojawić $z \nmid o$. Jest w niej zatem obecna jakaś fundamentalna skaza, niedoskonałość, ułomność. Czy nie taki jest sens grzechu pierworodnego? Leszek Kołakowski pisze:

Obecność diabła niedwuznacznie potwierdza, że zło stanowić będzie po wiek wieków nieusuwalny składnik świata i że czcze są wszelkie nadzieje na powszechną rekoncyliację. (...) Powiedzieć, że skażeni jesteśmy zasadniczą ułomnością i że diabeł nie może być nawrócony, znaczy to tyle, co powiedzieć, że spora część zła nie daje się usunąć i że w naszych niedolach jest coś nieuleczalnego. Nie znaczy to, że wszelkie rodzaje zła są wieczne, a wszelkie formy niedoli nieuchronne ${ }^{31}$.

A jaką antropologię odsłania to dramatyczne wydarzenie?

W sytuacji sponiewierania zakwestionowaniu ulega całe jestestwo ofiary. Ból nie jest tylko bólem ciała albo jedynie cierpieniem duszy. Cierpi cały człowiek. O czym to świadczy? Jeśli nawet człowiek jest istotą wielowymiarową czy wieloaspektową, jeśli nawet zachodzi w nim - na co istnieje wiele dowodów - jakieś fundamentalne pęknięcie czy wręcz rozdarcie, w gruncie rzeczy jest zintegrowana całościq i jednością. Emmanuel Mounier pisze: „Człowiek jest

${ }^{29}$ J. Tischner, Filozofia dramatu, dz. cyt., s. 125.

${ }^{30}$ M. Heller, Dobro Wszechświata, „Tygodnik Powszechny” 39 (2014), s. 53.

${ }^{31}$ L. Kołakowski, Czy diabeł może być zbawiony?, tłum. R. Zimand, „Znak” 9 (1981), s. $1176-1179$. 
ciałem $\mathrm{z}$ tego samego tytułu, $\mathrm{z}$ jakiego jest duchem: jest cały «ciałem» $\mathrm{i}$ cały «duchem»" 32 .

Zmaltretowany człowiek cierpi, żali się, lamentuje, rozpacza, buntuje się i pragnie popełnić samobójstwo. Nie jest zatem ani krewnym drzewa, ani nawet krewnym zwierzęcia. Jest bytem swoistym, oryginalnym, „nieredukowalnym" do reszty świata (Karol Wojtyła). A świadczy o tym między innymi fakt, że posiada wnętrze, sferę subiektywna, świadomość, w której pojawiają się przeżycia. Abraham J. Heschel pisze: „Człowiek zajmuje miejsce w fizycznej przestrzeni jak wszystkie konkretne byty. Jednak w przeciwieństwie do innych bytów jego autentyczna egzystencja rozgrywa się w przestrzeni wewnętrznej"33.

Czy jednak cierpienia doznaje jakiś bezosobowy, bezimienny strumień świadomości? Tak naprawdę cierpi jedyne i niepowtarzalne „ja”. Człowiek jawi się zatem również i w tym traumatycznym doświadczeniem jako istota egologiczna, mająca poczucie „ja”, o czym pisze między innymi Antoni Kępiński: „poczucie własnego «ja» jest zjawiskiem najbardziej pierwotnym" ${ }^{34}$.

W opisywanej sytuacji rozgrywa się dramat istnienia. Dobre bycie dziewczyny i chłopca zostało zaatakowane przez zło i radykalnie zakwestionowane. Okazało się byciem niedoskonałym, kruchym, nieposiadającym w sobie zabezpieczenia przed złem. Sponiewierane istnienie zapragnęło siebie przekreślić, unicestwić. Nastąpiło zwarcie woli bycia, dobrego bycia, z pokusą nicości. Sytuacja ta odsłania zatem doniosłą prawdę o człowieku, którą w XX wieku wyeksponował Heidegger - prawdę o szczególnej więzi człowieka z byciem, o tym, że „zamieszkuje on w bliskości bycia” ${ }^{35}$.

W sytuacji zmaltretowania ofiara jest całkowicie bierna i bezbronna. Wydawałoby się zatem, że osobę można zredukować do przeżywającego podmiotu. Jednak z czasem w ofierze pojawia się bunt i wybór dotyczący samobójstwa. Okazuje się, że i ta sytuacja, która zasadniczo odsłania prawdę o człowieku jako istocie pasywnej, tylko przeżywającej, wskazuje, że człowiek jest istotą obdarzoną wolnością. Tej prawdy antropologicznej dowodzą między innymi Hegel i Kierkegaard, Bergson, Scheler i Heidegger, Jaspers, Marcel i Sartre,

${ }^{32}$ E. Mounier, Wprowadzenie do egzystencjalizmów oraz zbiór innych prac, tłum. A. Bukowski i E. Krasnowolska, Warszawa 1964, s. 21.

${ }^{33}$ A. Heschel, Kim jest człowiek?, tłum. K. Wojtkowska, Warszawa-Łódź 2014, s. 31.

${ }^{34}$ A. Kępiński, Schizofrenia, Warszawa 1972, s. 179.

${ }^{35}$ M. Heidegger, Budować, mieszkać, myśleć. Eseje wybrane, tłum. K. Michalski i in., Warszawa 1977, s. 104. 
Mounier i Guardini oraz Fromm i Ricoeur. „Dla osoby - pisze Ingarden - jest mianowicie konstytutywne to, że jest ona punktem źródłowym możliwych decyzji opartych na zrozumieniu sytuacji wziętej w aspekcie wartości, a zarazem jest także zdolna realizować to, co sama postanowiła" ${ }^{36}$. Prawdę o wolności człowieka wyraża psychiatra Kępiński tak oto: „Najważniejszym sprawdzianem «ja», czyli sił integrujących, jest (...) akt woli” ${ }^{37}$.

Świadomość i wolność nie są jedynymi elementami konstytuującymi wnętrze człowieka, jego centrum osobowe. Mocna i głęboka reakcja emocjonalna ofiary na akt sponiewierania objawia osobę jako istotę obdarzoną sercem. Prawdę o randze serca w strukturze osoby pielęgnuje Biblia, a na gruncie filozoficznym została ona odkryta przez Pascala („Serce ma swoje racje, których nie zna rozum"), a w XX wieku rozwinęli ją przede wszystkim Scheler ${ }^{38}$ i Hildebrand ${ }^{39}$.

Analizując centrum osobowe człowieka, antropologowie - między innymi Hildebrand ${ }^{40}$ - dowodzą, że jest ono ukonstytuowane przez trzy ośrodki i trzy rodzaje energii: serce, rozum i wolę (wolność). Prawdę tę potwierdza również analizowana przeze mnie sytuacja. Gdyby w niej zwyciężył rozum, zło byłoby wykluczone. Tymczasem zwyciężyły namiętności. Tischner pisze: „nie ma dla niego [człowieka] większego niebezpieczeństwa jak bezmyślność. Wszędzie, gdzie jest nieszczęście, ma swój udział bezmyślność" ${ }^{41}$. Na temat relacji między rozumem a namiętnościami wypowiada się Otto F. Bollnow: „rozum i namiętności stanowią przeciwieństwa rzeczywiście nie do połączenia” ${ }^{42}$. A Hildebrand tę myśl zaostrza: „Brutalna dynamika tego stanu pogrąża w odmętach zarówno rozum, jak i wolne centrum osobowe" ${ }^{33}$. Na temat wielkości i piękna rozumu wygłoszono słusznie wiele pozytywnych opinii, a nawet hymnów pochwalnych, między innymi, że jest „ulubionym dzieckiem Boga”, przecież to on bowiem stoi na straży jednej z najcenniejszych wartości - praw-

${ }^{36}$ R. Ingarden, Książeczka o człowieku, Kraków 1972, s. 82.

${ }^{37}$ A. Kępiński, Schizofrenia, dz. cyt., s. 197.

${ }^{38}$ Por. M. Scheler, Istota i formy sympatii, tłum. A. Węgrzecki, Warszawa 1980; tenże, Ordo amoris, tłum. A. Węgrzecki, w: M. Grabowski (red.), O miłości Antologia, Toruń 1998, s. 13-47; tenże, Miłość i poznanie, w: M. Scheler, Wolność, miłość, świętość, tłum. G. Sowinski, Kraków 2004, s. 9-36.

${ }^{39}$ Por. D. von Hildebrand, Serce, tłum. J. Koźbiał, Poznań 1985.

${ }^{40}$ Por. tamże, s. 92-96.

${ }^{41}$ J. Tischner, Wędrówki w krainy filozofów, dz. cyt., s. 9.

${ }^{42}$ O.F. Bollnow, Rozum a siły irracjonalne, tłum. M. Pulkowska, „Znak” 11 (1979), s. 1204.

${ }^{43}$ D. von Hildebrand, Serce, dz. cyt., s. 57. 
dy. Jednak rozważane wydarzenie ukazuje także inne oblicze rozumu - jego kruchość i fakt, że nie działa on w próżni, lecz w towarzystwie popędów, namiętności itp.

Czy cierpienie, jakiego doznali od swoich ojców chłopiec i młoda kobieta, jest redukowalne do fizycznego bólu? Oczywiście bycie kopanym i bycie gwałconą jest również doznaniem bólu fizycznego. Jednak w sytuacji tej boli przede wszystkim sponiewierane człowieczeństwo, godność człowieka, jego wartość. Cierpienie to nie miałoby takiego właśnie charakteru, gdyby człowiek nie był obdarzony godnością i gdyby poczucie własnej wartości nie miało dla niego żadnego znaczenia. Sytuacja ta odsłania doniosłą prawdę o człowieku: że jest w swym rdzeniu - używając terminologii Tischnera - „ja” aksjologicznym i że jest obdarzony godnościq.

Zło związane ze zmaltretowaniem zaistniało w przestrzeni międzyosobowej i przyszło do osoby ze strony drugiego człowieka. Czy byłoby to możliwe, gdyby ofiary były monadami, samotnymi wyspami? Wydarzenie to odsłania zatem doniosłą prawdę o człowieku - że jest on istotą dialogiczną: otwartą i wrażliwą na inne osoby, żyjącą z nimi itd. Z kolei to, co zrobili krzywdziciele, dowodzi faktu, że relacje międzyosobowe nie są tylko nośnikami dobra, ale również zła - cierpienia, krzywdy, pogardy itp. Tę antropologiczną prawdę potwierdzają badania ważnego nurtu dwudziestowiecznej filozofii - dialogiki ${ }^{44}$.

Obraz człowieka, jaki wyłania się z tego dramatycznego i bolesnego doświadczenia, jest w gruncie rzeczy spójny, koherentny z agatologiczno-etycznym personalizmem komunijnym, który opracowuję już od wielu lat ${ }^{45}$.

Oczywiście analizowana sytuacja odsłania wiele innych, oprócz omówionych, prawd antropologicznych, w szczególności związanych z eschatologią człowieka. Wymieńmy je, jednak już ich nie rozwijając. Jednym z fundamentalnych doświadczeń człowieka jest przeżycie strachu i lęku, co dowodzi, że jesteśmy istotami skończonymi, ułomnymi. „Nasza ułomność nie jest czymś przypadkowym"46, lecz należy do istoty naszej kondycji. Nie jesteśmy w stanie wyeliminować całkowicie z naszego życia cierpienia, pustki egzystencjalnej i absurdu. Nie potrafimy wymknąć się śmierci. Jednak jesteśmy zdolni do odparcia pokusy samobójstwa. I wcale nie zawsze jest to motywowane tchórzo-

${ }^{44}$ Por. J. Tischner, Filozofia dramatu, dz. cyt.; A. Węgrzecki, Wokót filozofii spotkania, Kraków 2014; J.A. Kłoczowski, Filozofia dialogu, Poznań 2005.

${ }^{45}$ Por. J. Galarowicz, Być ziarnem pszenicznym. Nowa ksiażeczka o człowieku, Kęty 2006; tenże, Paradoks egzystencji etycznej (Inspiracje: Ingarden - Wojtyła - Tischner), Kraków 2009.

${ }^{46}$ L. Kołakowski, Czy diabeł może być zbawiony?, dz. cyt., s. 1181. 
stwem. Ośmiolatek i dwudziestopięciolatka odparli pokusę samobójstwa i nadal żyją, ponieważ ostatecznie zwyciężyła w ich duszach nadzieja i przeświadczenie, że mimo wszystko warto żyć. Człowiek jest bowiem istotą skierowaną na sens i zdolną do nadziei, również do Najwyższej Nadziei, że jest możliwe ostateczne ocalenie, absolutny sens i pełnia szczęścia.

\section{"Uniepotrzebnianie cierpienia"}

Autentyczna filozofia nie robi uniku przed pytaniem, jak żyć. Jeśli człowiek, który został tak bardzo skrzywdzony, że jego egzystencja uległa radykalnemu zakwestionowaniu, nie uległ pokucie samobójstwa, idzie przez życie z bolesnymi skutkami zranienia. Jego życie to los homo patiens. Norwid, a za nim Tischner mówili o „uniepotrzebnianiu męczeństwa”. Mądre życie polega również na tym, aby „uniepotrzebniać cierpienie” - minimalizować je, eliminować, zapobiegać jego przyczynom itd. W jaki sposób można „uniepotrzebniać cierpienie" człowieka brutalnie sponiewieranego? Pytanie to można zamienić na dwa inne: w jaki sposób homo patiens może pomóc sobie samemu? A jak mogą mu pomóc inne osoby? Natomiast w eseju pomijam zagadnienie zapobiegania tego rodzaju wydarzeniom. Podejmując ten dramatyczny problem, nie chcę wyręczać w rozwiązywaniu go psychologów, psychiatrów i psychoterapeutów oraz duszpasterzy; chcę jedynie sformułować zasady, na których powinna być oparta pomoc specjalistyczna i konkretna.

Najpierw chcę zwrócić uwagę na kilka zagrożeń, jakie czyhają na osobę bardzo pokrzywdzoną ${ }^{47}$. Podstawowym zagrożeniem jest pokusa totalnej ucieczki od siebie i swojej egzystencji - pokusa samobójstwa. Jeśli jednak człowiek oprze się tej pokusie, może ulegać innym formom ucieczki od tej dramatycznej sytuacji i obolałej egzystencji: może wycofywać się z życia, izolować się od ludzi oraz przekształcać dom w kryjówkę; może popadać w alkoholizm, narkomanię i seksoholizm; może opuścić dom, a nawet dokonać samookaleczenia (opisany przeze mnie przypadek) itp. Niekiedy ofiary przemocy, gwałtu itp. wypierają całkowicie ze świadomości te arcybolesne doświadczenia. Jednak przeżycia te pozostawiają w ich duszy głęboki ślad, dlatego dają o sobie znać w taki sposób, z którego ofiary te nie zdają sobie sprawy. Na przykład porzucona dziewczyna, która ten fakt całkowicie wyparła ze świadomości, swój ból i nienawiść do porzucającego wyraża poprzez agresję wobec innych męż-

\footnotetext{
${ }^{47}$ Por. J. Galarowicz, Odnaleźć sens w cierpieniu, dz. cyt., s. 163-173.
} 
czyzn. Niekiedy (często?) osoby bardzo zranione po prostu godzą się z tym, że są gorsze, pokrzywdzone, że niewiele znaczą, że jest im na tym świecie źle itd. Na pewno zagraża im również skłonność do ucieczki od odpowiedzialności.

A w jaki sposób człowiek sponiewierany i zraniony może pomóc sobie sa$m e m u$ ? Co powinien zrobić, aby oddalać od siebie powyższe zagrożenia? Jak on sam może leczyć podcięte korzenie własnej egzystencji? Poszukującemu odpowiedzi na te pytania nasuwają się dwa słowa: „prawda” i „męstwo" mądrego ustosunkowania się do tego bolesnego wydarzenia i jego skutków jest prawda - przyjęcie do wiadomości, że coś takiego faktycznie się wydarzyło; nie należy zatem od tej prawdy uciekać i jej wypierać. Wymaga to jednak męstwa. Zmierzenie się z tą bolesną prawdą nie jest tożsame z jej pielęgnowaniem, delektowaniem się nią, odnawianiem rany i wpatrywaniem się w przeszłość. Właściwą postawą wobec zła jest przede wszystkim skierowanie się ku przyszłości i nadzieja wsparta czynem. W tym dramatycznym ekstremalnym wydarzeniu nastąpiło radykalne zakwestionowanie egzystencji i poczucia własnej wartości, stąd fundamentalnym zadaniem człowieka jest przywracanie tego poczucia, odbudowywanie go i umacnianie się w nim. Jak to zrobić? Przede wszystkim należy rozwijać swoje zainteresowania i pasje, nie wstydzić się sukcesów itd. A po drugie, należy otwierać się na wszelkie dobro, którym - mimo doświadczenia tego straszliwego zła - jest człowiek obdarowywany, w szczególności na dobre, mądre i kochające osoby oraz na mądre książki, na piękno obecne w przyrodzie, sztuce, liturgii itp. Po trzecie - jedną z dróg uzdrowienia osoby zmaltretowanej i sponiewieranej jest po prostu czynienie przez nią samą dobra i pamiętanie o tym, co gdzieś napisał Tadeusz Żychiewicz: „Cokolwiek dobrego uczynisz, nie zginie". Wielkim zadaniem, przed jakim stoi tak dotkliwie zraniony człowiek, jest polubienie siebie i rozumienie siebie - swoich problemów, lęków, złych nastrojów, powracającego niepokoju, że się tak niewiele znaczy, a życie i świat są w istocie absurdalne itp.

Bardzo ważnym elementem przezwyciężania egzystencji radykalnie zakwestionowanej jest mądre ustosunkowanie się do krzywdziciela. Odruchowym, pierwotnym i uzasadnionym potraktowaniem go jest nienawiść, pogarda itp. oraz całkowite odcięcie się od niego. Jednak po pewnym czasie pokrzywdzony może sobie postawić pytanie, czy jest to jedyny sposób odnoszenia się do krzywdziciela i czy nie ma innej, mądrzejszej możliwości. I może odkryć, że faktycznie istnieje taka droga - a jest nią przebaczenie. Jeśli się mu to uda, ła-

${ }^{48}$ Por. tamże, s. $173-181$. 
twiej mu przyjdzie zrozumieć akt skrzywdzenia. Może się okazać, że krzywdziciel także kiedyś został bardzo pokrzywdzony.

Nie jesteśmy monadami, samotnymi wyspami, lecz istotami dialogicznymi i komunijnymi - żyjemy wśród innych osób, z nimi i również dla nich. Potworne zło zranienia przyszło do ofiary od drugiego człowieka. Ale przecież może od niego przyjść również dobro. W jaki sposób może pomóc zranionemu drugi człowiek? Odpowiedź na to pytanie poprzedzam krótką wypowiedzią na temat niewłaściwego odnoszenia się do pokrzywdzonego ${ }^{49}$. Można przyjąć wobec zranionego postawę obojętności i ucieczki od odpowiedzialności za niego. Częstym grzechem jest łatwe pocieszanie go, wymądrzanie się i moralizowanie. Krzywda, jaka spotkała drugiego, może być pretekstem do wywyższania się ponad niego, patrzenia na niego z góry: „on jest taki biedny, a ja jestem szczęściarzem, ponieważ mnie to ominęlo".

A w jaki sposób można pomóc zranionym - sponiewieranemu chłopcu, gwałconej przez ojca dziewczynie, zmaltretowanym kobietom i innym osobom znajdującym się w podobnej sytuacji?

Pytanie to jest skierowane w pierwszej kolejności do krzywdzicieli. Sprawca zła stoi przed wyborem: przyznać się do wyrządzonego zła, uznać swoją winę i wyrazić skruchę albo uciekać od winy - negując ją, zawężając sobie pole odpowiedzialności, eksponując własne nieszczęście, pozbywając się „nieznanego świadka”, obwiniać pokrzywdzonego itp..$^{50}$ Aktem, który ma fundamentalne znaczenie dla uzdrowienia pokrzywdzonego, jest przyznanie się przez krzywdziciela do winy w jego obecności i prośba o przebaczenie. A potem próba naprawienia wyrządzonego zła. Ile więcej byłoby na świecie dobra, gdyby sprawcy zła zdobyli się na takie właśnie postępowanie. Niestety, zdarza się to stosunkowo rzadko.

A w jaki sposób mogą pomóc osobom zmaltretowanym i sponiewieranym inni ludzie? Jest to zadanie niezwykle trudne, a czasem wręcz beznadziejne, ponieważ ten arcybolesny fakt jest na ogół przez nich głęboko ukrywany. Jednak osoby bliskie i przyjaciele, pedagogowie i duszpasterze mogą czasem zauważyć skutki tych dramatycznych i traumatycznych wydarzeń. Ich zadaniem jest wówczas próba przekonania pokrzywdzonych do otwarcia się i „zdradzenia pilnie strzeżonego sekretu”. Jeśli się im to uda, należy, oczywiście, podjąć dalsze kroki, kierując ich do odpowiednich poradni itp. Natomiast

\footnotetext{
${ }^{49}$ Por. tamże, s. 181-190.

${ }^{50}$ Por. tenże, Nowy elementarz etyczny, Kraków 2011, s. 108-119.
} 
w wyjątkowej sytuacji znajdują się spowiednicy, ponieważ zawsze mają możliwość zapytania penitenta, czy nie został skrzywdzony w ten właśnie sposób.

Jak widać, za „uniepotrzebnianie cierpienia” jest odpowiedzialny w omawianej sytuacji sam pokrzywdzony, jego bliscy, przyjaciele i wychowawcy, spowiednicy oraz ci wszyscy - czyli w istocie każdy z nas - którzy mogą, każdy na swój sposób, minimalizować zaistnienie sytuacji brutalnego sponiewierania człowieka przez człowieka.

Niechaj puentą tego eseju będą dwie myśli. Philippe Madre pisze: „znosić zło, poddawać się z rezygnacją jego nonsensowi nie jest postawą godną człowieka” ${ }^{1}$. A Tischner często cytował słynne słowa Norwida: „Cała tajemnica postępu ludzkości zależy na tym, aby coraz więcej stanowczo, przez wcielanie dobra i rozjaśnianie prawd, broń największa, jedyna, ostateczna, to jest $m e ̨-$ czeństwo, uniepotrzebniało się na ziemi" ${ }^{2}$.

Jan Galarowicz (ur. 1949, Łopuszna), dr, adiunkt na Wydziale Humanistycznym AGH w Krakowie (od 2015 emeryt), wykładowca w krakowskich seminariach duchownych. Autor m.in. Na ścieżkach prawdy. Wprowadzenie do filozofii, Kraków 1992; Człowiek jest osoba. Podstawy antropologii filozoficznej Karola Wojtyły, Kraków 1994, Kęty 2000; W drodze do etyki odpowiedzialności, t. 1-2, Kraków 1997-1998; Paradoks egzystencji etycznej. Inspiracje: Ingarden - Wojtyła - Tischner, Kraków 2009; Kochać naprawdę, Kraków 2011; Ks. Józef Tischner, Kraków 2013; Zrozumieć człowieka cierpiącego, Kraków 2014; Martin Heidegger: genialny myśliciel czy szaman?, Kraków 2014; Odnaleźć sens w cierpieniu, Kraków 2015; Szczęście na manowcach, Kęty 2017; Wprowadzenie do antropologii filozoficznej, Kęty 2018.

${ }^{51} \mathrm{Ph}$. Madre, Skandal zła, tłum. D. Zańko, Kraków 1996, s. 70.

${ }^{52}$ C.K. Norwid., Promethidion, w: tenże, Pisma wybrane, t. 2: Poematy, Warszawa 1980, s. 317.

DOI: http://dx.doi.org/10.15633/9788374386487.14 